\title{
Efficiency of charcoal production in Sub-Saharan Africa: Solutions beyond the kiln
}

\section{Jolien SCHURE ${ }^{1}$ \\ François PINTA ${ }^{2,3}$ \\ Paolo Omar CERUTTI ${ }^{1}$ \\ Lwanga KASEREKA-MUVATSI ${ }^{1}$}

${ }^{1}$ Center for International Forestry Research (CIFOR)

Jalan CIFOR, Situ Gede, Sindang Barang Bogor (Barat) 16115

Indonesia

\section{${ }^{2}$ CIRAD}

UPR BioWooEB

34398 Montpellier

France

\section{${ }^{3}$ BioWooEB}

Univ Montpellier

CIRAD

Montpellier

France

\section{Auteur correspondant /}

Corresponding author:

Jolien SCHURE -

j.schure@cgiar.org

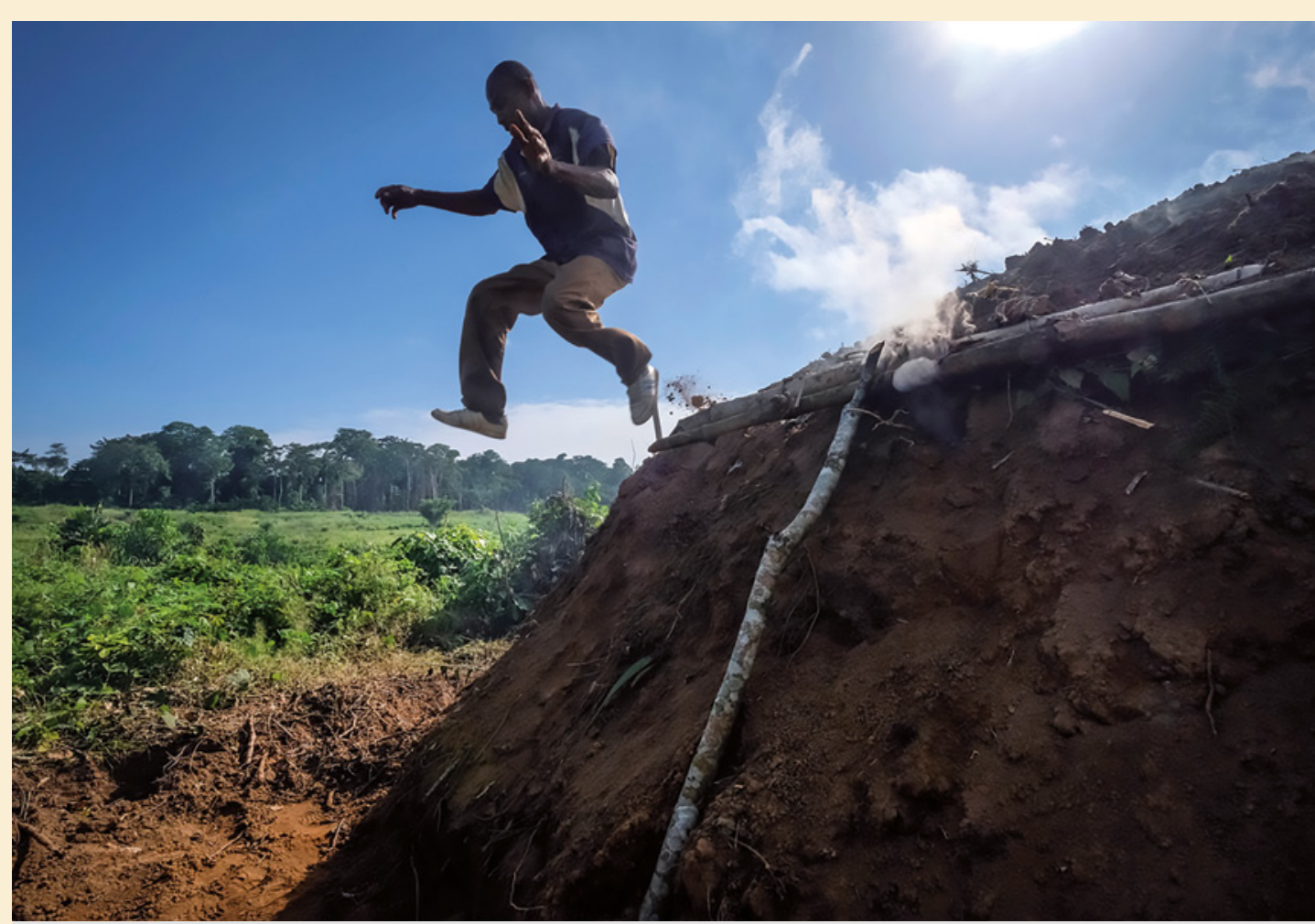

Photo 1.

Solutions "beyond the kiln"? Kiln near Yangambi, Democratic Republic of Congo.

Photo CIFOR/A. Fassio 2017.

Doi : 10.19182/bft2019.340.a31691 - Droit d'auteur (C) 2019, Bois et Forêts des Tropiques (c) Cirad - Date de soumission : 11 juillet 2018 ; date d'acceptation : 2 novembre 2018 ; date de publication : $1^{\text {er }}$ avril 2019.
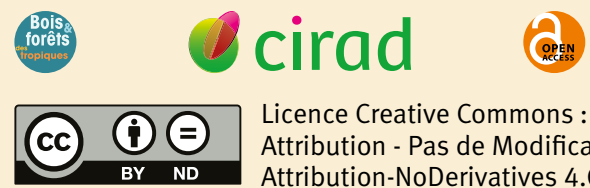

Licence Creative Commons :

Attribution - Pas de Modification 4.0 International.

Attribution-NoDerivatives 4.0 International (CC BY-ND 4.0)
Citer l'article / To cite the article

Schure J., Pinta F., Cerutti P. O., Kasereka-Muvatsi L., 2019. Efficiency of charcoal production in Sub-Saharan Africa: Solutions beyond the kiln. Bois et Forêts des Tropiques, 340: 57-70. Doi : https://doi.org/10.19182/ bft2019.340.a31691 


\section{RÉSUMÉ}

\section{Efficacité de la production de charbon de bois en Afrique subsaharienne : des solutions au-delà de la performance du four}

Le charbon de bois restera une source d'énergie importante en Afrique subsaharienne dans un avenir prévisible, le présent article se concentre sur l'amélioration de l'efficacité de la carbonisation comme contribution à des chaînes de valeur plus durables du charbon de bois. Alors que l'efficacité de la conversion du bois en charbon est souvent considérée comme une question technique de performance des fours, cette étude vise à mettre en lumière le rôle d'un contexte institutionnel favorable et les capacités des acteurs impliqués. Sont d'abord passées en revue les initiatives visant à améliorer la production de charbon de bois dans différents pays d'Afrique subsaharienne. Nous comparons ensuite les données sur les processus de carbonisation dans deux zones en République démocratique du Congo : Yangambi et le Plateau de Bateke. Les principales conclusions sont les suivantes : 1) l'amélioration des techniques de carbonisation permet de réaliser d'importants gains en termes de taux de conversion du bois en charbon, mais le succès dépend en grande partie de l'adéquation des solutions de four en fonction du contexte, de la capacité et de la sensibilisation des producteurs et du contexte institutionnel favorable ; 2 ) le renforcement des capacités des opérateurs et des autres parties prenantes nécessite des techniques de four efficaces, mais aussi une sensibilisation accrue aux avantages et aux options d'approvisionnement durable, le renforcement des compétences financières et de gestion des organisations de producteurs et l'amélioration du transport, de la manutention et de la commercialisation ; 3) le statut illégal ou informel des producteurs de charbon de bois en Afrique subsaharienne nuit à l'efficacité des processus de production du charbon, tandis qu'un cadre institutionnel adéquat facilite l'accès des producteurs aux permis et au financement, fournit une fiscalité claire avec des incitations pour des pratiques plus durables et relie les exigences techniques en termes de carbonisation aux sources et utilisations finales durables. Le succès ou l'échec des techniques de carbonisation améliorées et les résultats socio-écologiques connexes sont déterminés conjointement par les solutions qui incluent les aspects de renforcement des capacités, d'acceptabilité et d'institutions favorables identifiés dans cet article. La poursuite du développement de ces solutions en partenariat avec les producteurs accroît le potentiel de chaînes de valeur plus durables pour le bois-énergie.

Mots-clés : charbon de bois, bois-énergie, four, forêt, paysage, informel, carbonisation, rendement massique, Afrique subsaharienne.

\section{ABSTRACT}

\author{
Efficiency of charcoal production in Sub- \\ Saharan Africa: solutions beyond the \\ kiln
}

With charcoal set to remain an important energy source throughout Sub-Saharan Africa (SSA) in the foreseeable future, this paper focuses on improving the efficiency of carbonisation as one contribution to more sustainable charcoal value chains. While the efficiency of woodto-charcoal conversion is often considered a technical matter of kiln performance, this study aims to shed light on the role of the enabling institutional context and the capacities of the players involved. We first review initiatives for enhanced charcoal production in different SSA countries. We then compare the data on carbonisation processes in two production areas in the Democratic Republic of Congo: Yangambi and the Bateke Plateau. The main findings are: 1) Large gains in wood-to-charcoal conversion rates are possible by improving carbonisation techniques, but success largely depends on the context-specific appropriateness of kiln solutions, on the capacity and awareness of producers and on the enabling institutional context. 2) Enhancing capacity among operators and other stakeholders requires efficient kiln techniques, but also raising awareness on benefits and sustainable sourcing options, building financial and management skills among producer organisations and improving transportation, handling and marketing. 3) The illegal or informal status of charcoal producers across SSA detracts from the efficiency of charcoal production processes, while an enabling institutional framework facilitates producers' access to permits and funding, provides for simple taxation with incentives for more sustainable practices and links technical requirements for carbonisation to sustainable sourcing and end-uses. The success or failure of improved kiln techniques and related socio-ecological outcomes is co-determined by solutions that include the aspects of capacity enhancement, acceptability and enabling institutions identified in this paper. Further development of these solutions in partnership with producers enhances the potential for more sustainable fuelwood value chains.

Keywords: charcoal, fuelwood, kiln, forest, landscape, informal, carbonisation, mass yield, Sub-Saharan Africa.

\section{RESUMEN}

\section{Eficiencia de la producción de carbón vegetal en el África subsahariana: soluciones más allá del rendimiento de la carbonera}

Con el carbón vegetal manteniéndose como una importante fuente de energía a través del África subsahariana (SSA) en el futuro previsible, este artículo se centra en mejorar la eficiencia de la carbonización como una de las intervenciones que contribuye a una cadena de valor del carbón vegetal más sostenible. Mientras la eficiencia de la conversión de la madera en carbón vegetal se considera un aspecto técnico del rendimiento de las carboneras, este estudio pretende arrojar luz sobre el rol de la habilitación del contexto institucional y de las capacidades de los actores implicados. Primeramente, revisamos las iniciativas de producción mejorada de carbón vegetal en diferentes países del SSA. Seguidamente comparamos los datos de los procesos de carbonización en dos áreas productivas de la República Democrática del Congo: Yangambi y la meseta Bateke. Los principales descubrimientos son: 1) Es posible aumentar considerablemente las tasas de conversión de madera a carbón vegetal mejorando las técnicas de carbonización; pero el éxito depende ampliamente de la pertinencia específica en el contexto de las soluciones para las carboneras, de la capacidad y concienciación de los productores y de la habilitación del contexto institucional. 2) Mejorar la capacidad entre los operadores y otras partes interesadas requiere técnicas eficientes para las carboneras, pero también incrementar la conciencia de los beneficios y las opciones de aprovisionamiento sostenible, desarrollar capacidades financieras y de gestión entre las organizaciones productoras, y mejorar el transporte, la manipulación y el marketing. 3) La situación ilegal o informal de los productores de carbón vegetal a través del SSA le resta valor a la eficiencia de los procesos de producción de carbón vegetal, mientras que la habilitación del marco institucional facilita el acceso de los productores a los permisos y los fondos, proporciona con una simple tasación incentivos para prácticas más sostenibles y vincula los requisitos técnicos de la carbonización con fuentes sostenibles y utilizaciones finales. El éxito o fracaso de las técnicas mejoradas para las carboneras y los resultados socioecológicos relacionados está determinado al mismo tiempo por soluciones que incluyen los aspectos de mejora de capacidad, aceptabilidad y habilitación de las instituciones identificadas en este estudio. Un desarrollo más extenso de estas soluciones en asociación con los productores mejora el potencial para cadenas de valor más sostenibles de la energía procedente de la leña.

Palabras clave: carbón vegetal, leña, carbonera, bosque, paisaje, informal, carbonización, rendimiento másico, África subsahariana. 


\section{Introduction}

\section{Charcoal in Sub-Saharan Africa}

Woodfuel remains an important source of energy for cooking and economic activities in large parts of the world, with global consumption of around 1.86 billion $\mathrm{m}^{3}$ in 2016 (FAO, 2018). Whereas total woodfuel consumption has been declining or stabilizing in Asia and South America, in Sub-Saharan Africa (SSA) woodfuel demand continues to increase. Biomass accounts for around $60 \%$ of total energy demand in SSA, with considerable differences between countries (IEA, 2017). Despite existing global targets, as described in Sustainable Development Goal $N^{\circ} 7$, to have access to sustainable energy by 2030 with preferred household energy access to Liquid Petroleum Gas (LPG), natural gas and electricity in urban areas of developing regions (United Nations, 2015), over $90 \%$ of households in SSA rely on woodfuels for cooking. Unless major energy shifts occur, it is expected that total number of people relying on biomass in SSA keeps growing to 820 million in 2030 (representing $56 \%$ of population) (IEA, 2017).

Whereas in rural areas use of firewood dominates, charcoal is a common source of cooking energy in urban centres of SSA and its use is expected to increase in the coming decades (Mwampamba et al., 2013). Most charcoal is produced, processed and transported informally, outside existing legal frameworks (Owen et al., 2013; Schure et al., 2015). Charcoal has attractive characteristics as a renewable fuel type. It can be sourced from sustainably produced feedstock, processed with efficient technology, and it provides a product that has relatively high energy content (between $28-33 \mathrm{MJ} / \mathrm{kg}$ ), is highly reactive, reaches high temperatures suitable for metal smelting and other industries, and is easy to store and handle compared to firewood (Antal and Grønli, 2003). Charcoal is preferred over firewood by households because it produces less smoke, provides a preferred taste to certain dishes and burns regularly without constantly attending to the fire (Smeets et al., 2012; Kammen and Lew, 2005). The process of converting biomass to charcoal requires pyrolysis, which is the thermochemical decomposition of organic materials into (non-condensable and condensable) gases and solid materials (charcoal, biochar) in a low-oxygen environment (Girard and Napoli, 2005). Most charcoal in SSA is produced in traditional earth-mound kilns with efficiency rates of around $13 \%$ to $15 \%$ (FAO, 2017a; Schenkel et al., 1997).

The production process generally consists of the following steps:

1. Cutting the wood. The wood can be sourced from natural forest lands or farmlands and consists of targeted tree species or wood residues from clearing land for agriculture or timber logging.

2. Drying of the wood.

3. Preparing the venue by clearing the place where the kiln is to be build and possibly digging of ventilation holes and/or positioning of two main supporting logs.

4. Piling of the wood.

5. Covering the wood with leaves, sticks and earth.

6. Lighting the kiln (through the fire hole).

7. Monitoring the carbonisation process, including repairing of the kiln when needed.

8. Emptying the kiln, directly after carbonisation.

9. Cooling of the charcoal, sometimes aided with earth or water.

10. Filling bags and packaging for transportation.

In the absence of short-term alternatives to charcoal (Mwampamba et al., 2013) and expected continuous increase of its demand in SSA (IEA, 2017), solutions are needed to render charcoal value chains more sustainable. This study focusses on options to improve the phase of carbonisation, noting that any proposed solution should be based on context-based woodfuel value chain analyses and target multiple options simultaneously (table I).

Table I.

Options for interventions for more sustainable charcoal throughout the value chain.

\section{Phase of charcoal value chain Types of options}

Sourcing of wood 


\section{Efficiency of charcoal production in Sub-Saharan Africa}

An efficient charcoal carbonisation technique produces the greatest quantity of good quality charcoal from the smallest amount of wood and labour input while being economically viable (Wartluft and White, 1984). Improved kilns can contribute to less emissions by saving wood input and by Green House Gas (GHG) reducing kiln technologies that capture or recycle part of pyrolysis gases (Mwampamba et al., 2013). Improved Charcoal Production Systems (ICPS) can increase dry basis efficiencies up to 30 to $35 \%$, as compared to average $13-15 \%$ of earth kilns, and reduce emissions by up to $75 \%$ compared to traditional earth kilns (Sparrevik et al., 2015) (table II). Co-generation of heat and power from charcoal production by a sequence of adapted charcoal kilns could contribute to energy supply in rural areas (de Miranda et al., 2013).

Projects for improved kiln techniques have received relatively little attention and investments and adoption of improved kiln technology is low throughout SSA (Smeets et al., 2012). Reasons given for this low uptake are the difficulties of implementation and control within the overall informal sector, the relatively high investment costs of improved kiln types, the impracticality of having a stationary kiln while lacking means of transporting the wood and the lack of skills and training to construct or operate the kilns (van Beukering et al., 2007; GIZ, 2015; liyama et al., 2014; Smeets et al., 2012). The efficiency of carbonisation depends not only on the type of kiln used, but also on other factors, notably wood properties, including wood moisture, wood density and diameter log, and skills of producers in efficient kiln construction, involving drying of the wood, proper wood arrangement and monitoring of the carbonisation process (Antal and Grønli, 2003; Kammen and Lew, 2005; Malimbwi et al., 2000; Ojelel et al., 2015).

The present study contributes to improved understanding on factors co-determining the efficiency of carbonisation processes, by looking in more depth into capacities and enabling institutional factors

\section{Objective}

This paper focusses on improving efficiency of carbonisation as one of the interventions that could contribute to more sustainable charcoal value chains in Sub-Saharan Africa. Improved efficiency could in theory contribute a considerable part to mitigation efforts and more sustainable woodfuel value chains (FAO, 2017a). In practice, uptake of more efficient techniques and investments in these initiatives remain low (Smeets et al., 2012). First, we provide a review of initiatives targeting enhanced efficiency of charcoal production in different SSA contexts. Subsequently, we conduct a comparison of data on the efficiency of carbonisation from two production areas in the DRC: Yangambi and the Plateau Bateke landscape. Based on the review, field data and lessons from the case studies, we aim to shed light on factors of enabling institutional context and capacity enhancement of actors involved and the potential of improved wood-to-charcoal conversion with preferred socio-ecological outcomes in SSA context.

\section{Methodology}

The central concept "efficiency of carbonisation process" is defined as "adoption of improved wood-to-charcoal conversion practices with preferred socio-ecological outcomes" (figure 1). Preferred socio-ecological outcomes are understood as significant reduction of wood input needed for a certain volume of charcoal produced and accessibility and economic benefits for operators in terms of cost-benefits and materials involved. We consider the efficiency of the carbonisation process as the outcome of three interacting enabling factors: "appropriate techniques and technology", "capacity enhancement" and "enabling institutional context".

The following methods were used for data collection and analysis:

- Literature review: literature and grey literature (reports) were collected and content-wise analysed on subjects related to efficiency of carbonisation and enabling factors. Published data on charcoal production in the Plateau Bateke landscape was used to compare with new field data collected in the Yangambi landscape. The original field study from Plateau Bateke with monitoring of 10 earth kilns was conducted near Mbankana, $170 \mathrm{~km}$ north-east of Kinshasa on the RN16 road in four partner villages of the Makala project: Nsuni, Yolo, Imbu and Mampu (Pinta et al., 2013).

- Expert consultation: mail-exchanges with key project informants served to review lessons from five different initiatives in Cameroon, Madagascar, Kenya, Rwanda and Senegal and to collect up-to-date information. Consultation with the lead researcher and co-author of this paper provided insights in the comparative character of field data from Plateau Bateke and Yangambi landscape.

- Field data collection: The field data near the Yangambi Man and Biosphere Reserve (YMAB) was collected as part of a baseline study on woodfuel value chains in the area, conducted between June and December 2017. The data collection included surveys with operators, interviews with key stakeholders and monitoring of 10 charcoal kilns during operations (Projet Forêts, 2018). Selection of the 10 kilns took place in the main production areas, in the villages Okito, Bosukulu and Lomboto, upon approval of the head-producer. Measurements, by use of scales and a humidity meter, were taken at each kiln to determine mass $(\mathrm{PH})$ and humidity $(\mathrm{H} \%)$ of wood input and mass of charcoal output (PC) and mass of unburnt wood (I). The charcoal yield efficiency, by mass on dry basis $(\mathrm{PO}=$ $\left.P H^{*}[1-H \% / 100]\right)$ was calculated by the formula: $R=((P C /$ $(P O-I)) * 100$ (Girard, 1992). Descriptive statistics presented mean values and standard deviations of kiln data for the two areas. Comparative analysis of statistical differences was conducted by applying the non-parametric Mann-Whitney $\mathrm{U}$ test using STATA software. Data on the production process was collected using a structured protocol for noting down information on duration, number of persons involved and specific observations per step of the process. 


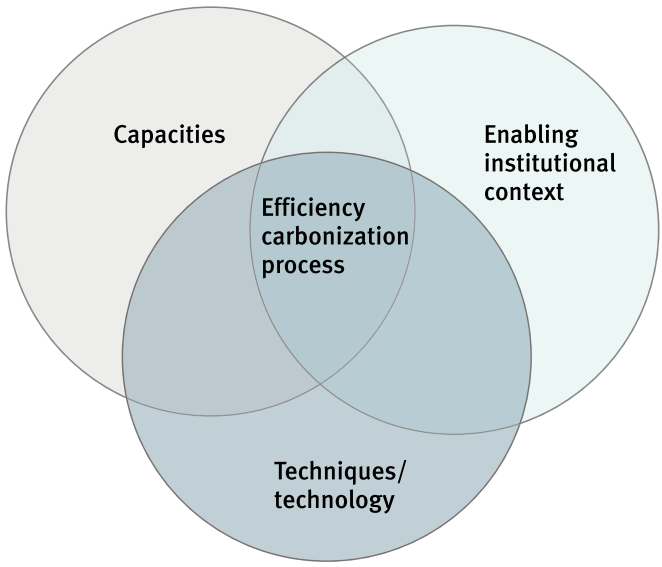

Figure 1.

Conceptual diagram on efficiency of carbonisation process.

\section{Results}

\section{Efficiency of charcoal production and enabling factors in Sub-Saharan Africa}

The following sections present findings on the contribution of capacity enhancement of actors involved and enabling institutions to more efficient carbonisation processes. The first section presents findings from five initiatives in Cameroon, Madagascar, Kenya, Rwanda and Senegal. The second section presents findings from two production areas in the Democratic Republic of Congo.

\section{Experiences of improving efficiency of charcoal making and enabling factors in SSA}

Several initiatives have targeted improved charcoal making and efficiency in SSA. We selected several documented cases, as summarized here below, to illustrate different types of interventions and to extract lessons on "capacity enhancement" and "enabling institutions" for more efficient carbonisation processes in SSA. These elements extracted are presented in an overview table (table III).

In Cameroon, the German Development Cooperation (GIZ) works together with stakeholders towards modernization of woodfuel value chains. One of its main initiatives is supporting carbonisation of wood residues from logging concessions, with an estimated potential of about 500,000 $\mathrm{m}^{3}$ of wood from concessions in East Cameroon to supply the woodfuel-deficient Far North Region. Increased efficiency of charcoal production, combined with use of wood residues that otherwise would be burnt without any added value, contribute to reducing GHGs while offering benefits to communities. The willingness of concession holders to provide the needed logistics and the enabling policy environment for trading sustainably produced charcoal while competing with informal produce need to be improved. Bribery during transportation remains one of the major impediments for cost-effective trade of the more sustainably produced and sourced charcoal to areas with high demand (GIZ et al., 2016ab; GIZ, pers. com, 2018).

In Madagascar, GIZ worked since 1996 to create a green charcoal chain for Antsiranana in northern Madagascar. It comprised reforestation schemes (mainly Eucalyptus and some Acacia) together with smallholders on 9,000 hectares of degraded lands and improving efficiency by introducing of improved kilns, such as the stationary Green Mad Retort (GMDR). Plots were allocated to individual households through a participatory process and these households were assisted acquiring official land tenure rights. Groups of plantation owners and charcoal makers developed business plans that correspond with the management plan of plantation areas and included investment in the retort and commercialization of the product. The afforested areas, combined with more efficient kiln technology can produce 4,000 tonnes of charcoal annually, supplying around 38,000 people with sustainably produced charcoal (GIZ, 2015; Etter et al., 2014; GIZ, pers. com., 2018).

In Rwanda, most charcoal is produced in earth-mound kilns with an average efficiency of around $11 \%$. The Sustainable Energy for All (SE4ALL) Action Agenda that targets improved charcoal mass yield from $11 \%$ (in 2015) to $15 \%$ by 2020 and $18 \%$ by 2030 , covers an expected contribution of $30 \%$ reduction of the predicted gap between supply and demand, representing 630,000 tons of wood (SE4ALL, 2015). Over the past few years, there have been a number of initiatives (by i.e. IFDC, Care International, the PAREF initiative), to train cooperatives and to introduce improved kiln types with higher efficiencies, of which the "rectangular" on the hillside (or the flat) and the adapted round Casamance kiln seemed most appropriate. Both kiln types use small portable chimneys and have higher efficiencies and net benefits. Some producers are reluctant to use portable chimneys as these make them more visible to controlling entities with possible repercussions for operating informally. A difference was noted between measured efficiency gains of improved techniques and perceptions by producers on improvements (DFS and EMS, 2016). Different types of fixed or stationary kilns that were introduced, such as Adam-retort kiln and the half-orange kiln, were not adopted beyond the project phase because of lack of concentrated wood supply, difficulties transporting the wood to the kiln and high investment costs (DFS and EMS, 2016; Owen et al., 2013; EMS, pers. com, 2018).

In Kenya, efficiency of the traditional earth-mound kilns used varies widely, from 10 to $30 \%$, and is generally low compared to improved kilns solutions. Traditional kilns are nevertheless often preferred because of low investment costs needed, portability, flexibility in size, and less skills needed to operate them (liyama et al., 2014). Following the Kenyan Charcoal Policy of 2009, the Kenya Forestry Research Institute (KEFRI) developed a manual and training materials on improved charcoal kilns, showcasing four technologies: improved earth kilns, a portable metal kiln, a drum kiln and the Casamance kiln, with higher yields between 27 to $30 \%$ 
and improved charcoal quality (Oduor et al., 2006). Officially, charcoal producer groups are required to use one of the improved kiln techniques. However, in practice most charcoal producers still use traditional kiln techniques (Angwere and Kipchirchir, 2016; Mutimba and Barasa, 2005; Njenga, pers. com, 2018).

In Senegal, the Casamance kiln was first developed and its technique was spread by numerous initiatives throughout SSA. The Casamance kiln is equipped with a chimney that allows for a better control of the airflow and partly re-directing hot flue gases into the kiln. Due to this reverse, carbonisation is faster and more uniform, producing a higher quality charcoal and efficiency of up to 30\% (BTG Biomass Technology Group, 2010). The Casamance kiln can be constructed at fairly low costs, involving only purchase of the chimney. In Senegal, the application of this technique was required of all communities that entered in a forest management agreement. Still, many charcoal makers did not continue using the technique, as they were reluctant to invest in a new chimney and not fully convinced of the benefits of the technique (GIZ, 2015). Some scholars found that traditional kilns can indeed be as efficient or even more efficient compared to the Casamance kiln, suggesting that producers' skills and dryness of feedstock are more important factors explaining efficiency (Chidumayo and Gumbo, 2013; Girard, 1992; Kammen and Lew, 2005).

Though different cases represent different lessons on enabling factors, there are some similarities in terms of need for context-specific kiln solutions with suitable and available materials. Acceptability of technique to producers, in terms of transportation limits, wood sizes and significant visible improvements, is important in explaining uptake. Enabling conditions are: access to finance, facilitation and capacitating of producer groups and recognition of their legal status.

Table II

Kiln types and efficiencies.

\begin{tabular}{|c|c|c|}
\hline Kiln type & Description & $\begin{array}{c}\text { Efficiency } \\
\text { (\% mass yield) }\end{array}$ \\
\hline Earth-pit & Wood in pit, covered with grass in soil. & $12-30$ \\
\hline Earth-mound & Wood piled on surface, covered with leaves and soil. & $9-30$ \\
\hline Casamance Earth-mound & $\begin{array}{l}\text { The surface earth kiln, equipped with chimney for } \\
\text { improved pyrolysis and quicker carbonisation. }\end{array}$ & $17-30$ \\
\hline Metal & Mobile metal kilns with chimney. & $12-30$ \\
\hline Brick and orange & Stationary brick kiln. & $13-32$ \\
\hline Retort & $\begin{array}{l}\text { Kiln with retort technology that returns wood gases } \\
\text { to the carbonisation chamber for more complete pyrolysis } \\
\text { and reduced emissions. Option to integrate a modified } \\
\text { chimney to recover oils and tars. }\end{array}$ & $22-35$ \\
\hline $\begin{array}{l}\text { CML plant } \\
\text { Ex (industrial) }\end{array}$ & $\begin{array}{l}\text { A cyclical process of twelve carbonisation entities and an } \\
\text { external combustion chamber. Each kiln is start one after } \\
\text { the others to permit the collection and incineration of the } \\
\text { carbonisation gases. Options to use heat for drying or to } \\
\text { produce heat and power. }\end{array}$ & $\begin{array}{l}30-32 \\
\text { (plus heat } \\
\text { or power) }\end{array}$ \\
\hline VMR oven (industrial) & $\begin{array}{l}\text { A cyclical process of two carbonisation entities and an } \\
\text { external combustion chamber. While carbonisation takes } \\
\text { place in one canister, the wood in the other canister is } \\
\text { being dried. }\end{array}$ & $30-32$ \\
\hline The Degussa (Reichert) & $\begin{array}{l}\text { Batch-fed retort where pyrolysis gasses are fed back to the } \\
\text { retort and excess gasses are burnt to operate the heat } \\
\text { exchanger and pre-dry the feedstock. }\end{array}$ & 34 \\
\hline Carbonex & $\begin{array}{l}\text { A cyclical process of eight carbonisation entities and an } \\
\text { external combustion chamber. Each kiln is started one after } \\
\text { the others to permit the collection of carbonisation gases. } \\
\text { The combustion provides heat for drying or producing power } \\
\text { with high efficiencies. }\end{array}$ & $\begin{array}{l}\quad 30-32 \\
\text { (plus heat } \\
\text { and power) }\end{array}$ \\
\hline Continuous operation retort & $\begin{array}{l}\text { Continuous carbonisation process retort such as the } \\
\text { Lambiotte and SIFIC process, where biomass is conveyed } \\
\text { through continuous stages of heating and drying, } \\
\text { carbonisation and cooling, in which pyrolysis gases } \\
\text { produced sustain the process and emissions are largely } \\
\text { mitigated. }\end{array}$ & $30-35$ \\
\hline
\end{tabular}

Adapted from FAO, 2017a, complemented by authors. 
Table III.

Lessons from interventions targeting improved charcoal conversion processes: technology, capacity enhancement, institutional framework.

\begin{tabular}{|c|c|}
\hline Case study & Technology \\
\hline $\begin{array}{l}\text { East-Cameroon: } \\
\text { Partnership } \\
\text { by Deutsche } \\
\text { Gesellschaft für } \\
\text { Internationale } \\
\text { Zusammenarbeit } \\
\text { (GIZ) with timber } \\
\text { companies to } \\
\text { transform wood } \\
\text { residues into } \\
\text { charcoal }\end{array}$ & $\begin{array}{l}\text { More advanced kiln types } \\
\text { (metal kiln, retort kiln) showed } \\
\text { varying performances, with } \\
\text { the retort kiln exceeding } \\
\text { performance of large } \\
\text { traditional kilns. Uptake and } \\
\text { interest remained low due to } \\
\text { needed technical skills and } \\
\text { professionalization of operator, } \\
\text { appropriate materials and } \\
\text { upfront investments. }\end{array}$ \\
\hline
\end{tabular}

Northern

Madagascar:

Reforestation

and improved

kiln integrated

value chain

approach by GIZ
The GMDR kiln in combination with the fast-growing plantation with short rotation cycle is suitable for its high and consistent efficiency (of around $30 \%$ ) and reasonable investment costs (3,000 USD). Around 120 ha provide feedstock to run one GMDR continuously.

\section{Capacity}

Support to organisation of charcoal producers, including financial and management skills.

Collaboration with charcoal organisations for appropriation of improved carbonisation techniques and training on efficiency and safety (improved traditional kiln or Casamance kiln).

Collaboration and awareness with concession holders for supplying wood residues to producers.

Improve transportation, including loading and stocking depots and contracts between producers and transporters.

Improve commercialization, including promoting of charcoal from residues, marketing and labelling.

Improve capacity of agents and administration to manage charcoal sector.

Combine establishment of sustainable wood production with participatory approach.

Advanced kiln requires training and professionalization of producers, as well as interest among local population to become fulltime kiln operator.

\section{Institutional framework}

Recognition of legal status charcoal producer groups and access to sustainably produced wood residues.

Charcoal production standards and regulatory framework.

Incentives for sustainably produced charcoal (e.g. differentiated taxes, controls) to compete with illegally produced charcoal and developing of national chain of custody for traceability.

Support by private sector and other institutional partners to lift benefits to national level.

Overcome issues of corruption and bribery on charcoal trade.

Undertaking of environmental impact assessments of charcoal production sites.

Provide sufficient time to small-scale energy enterprises to develop their operations before imposing taxes and additional standards (certification, packaging, labelling etc.).

Train NGOs to bridge the gap between government and communities.

Conducive governance landscape ("Vision 2020") and decentralized management provided enabling context.

Tenure security for individual households provide important incentive.

Legal trade provides income to communities and forest administration through taxes and fees.

Cooperatives' commitment to implementing improved techniques and efficient training.

Easier access to permits for cutting trees on own land.

Sufficient training, support, promotion and follow up on improved kiln techniques, including awareness raising on benefits.

Access to finance for the first purchase of materials.

Link technical requirements of kiln technology to sustainable sourcing and management plans, such as Development of District Forest Management plans and forest management plans.

Awareness on benefits of improved charcoal production and improved charcoal, with central and local governments, financial institutions and consumers.

Simplified and uniform charcoal taxation.

Kenya: guide on improved kiln techniques
Kiln design needs to consider transportation limits and sizes of wood/ branches harvested.
Senegal: introduction of Casamance kiln
Need for proven efficiency or quality enhancement before introducing technique.

Kilns need to be adapted to weather conditions.
Enhancement of technical capacity of charcoal producers.

More research needed on optimizing efficiencies of improved kilns.

Training should be accompanied by awareness raising on benefit kiln.

Need for availability of materials and finances for materials (chimneys).
Need for a light mechanism to monitor use of improved kiln technique. 
Capacity enhancement include: financial and management skills of producer organisations, efficient kiln techniques, awareness on benefits, improved transportation and handling and marketing to end users. An enabling institutional framework facilitates producers' access to permits, provides simple taxation with incentives for more sustainable practices and links technical requirements to sustainable sourcing and management plans.

\section{Efficiency of charcoal making: data and lessons from two production areas in the Democratic Republic of Congo}

Charcoal efficiencies in two production areas in the Democratic Republic of Congo (DRC) are presented in the following section, followed by assessment of differences in capacity of charcoal producers and the institutional framework (figure 2).

\section{Efficiency of wood-to-charcoal conversion near Yangambi Man and Biosphere Reserve and Plateau Bateke}

In both production areas, as throughout the rest of the country, charcoal is produced in traditional earth-mound kilns.

The UNESCO status Yangambi Man and Biosphere (YMAB) reserve covers around 220,000 hectares of tropical forest landscape in the Tshopo Province of the DRC. The YMAB serves simultaneously conservation, sustainable development and educational purposes (Raghunathan et al., 2013), but is not effectively managed at present, due to lack of management plan, clarity on land use boundaries and increased pressure from a growing population (Doumenge et al., 2015). Charcoal from this area supplies the local market and urban markets, representing an estimated annual volume of 13 thousand tons (Projet Forêts, 2018). The urban centre of Kisangani, with an estimated population of about 1.5 million inhabitants located about $90 \mathrm{~km}$ East of Yangambi, is the major centre of demand.

Plateau Bateke (PB), covered by savannah vegetation interspersed with gallery forests, stretches into south-eastern Gabon, the Republic of Congo and the DRC. The PB area is one of the main supply zones of the capital city Kinshasa with over 10 million inhabitants, supplying an estimated $40 \%$ of its total demand (Projet Makala, 2011). The area has known a significant reduction of forest stock and degradation due to shifting cultivation and charcoal production, with an estimated decrease of carbon stock by $75 \%$ over 20 years' time (Gond et al., 2016).

Comparing data on kilns monitored in both areas (table IV, annexes 1 and 2) shows differences in mean kiln characteristics and kiln efficiencies. A Mann-Whitney $U$ test revealed statistical difference of wood-to-charcoal-conversion efficiencies $(z=3.780, p=0.0002, r=0.42)$ and net efficiencies ( $z=3.787, p=0.0002, r=0.85)$ between the two production areas. Average efficiency of mass yield in YMAB was $12.8 \%(S D=5.0)$ on dry wood basis, whereas on Plateau Bateke the average efficiency amounts $28.1 \%(S D=3.1)$. The significant differences in humidity of the wood $(P<0.05)$ is one factor explaining differences in yield, whereas the mass wood input and percentage of unburnt wood did not differ significantly between the two areas. The larger variation of efficiencies measured in YMAB is due to some kilns with very low yields. The kilns monitored on PB did not include any "failed" production cycles, which explains to some extent the high average efficiency figure.

Capacities and institutional context for charcoal making near Yangambi Man and Biosphere Reserve and Plateau Bateke

In both areas, producers generally have years of experience producing charcoal. Nonetheless, clear differences in capacities of constructing good quality kilns have been observed, which explains in part the disparities in efficiency. On Plateau Bateke, producers undertook more frequently good practices of drying the wood, adding ventilation canals during assembly and
Map of two production areas, Yangambi Man and Biosphere reserve and Plateau

Bateke, in the Democratic Republic of Congo. 
Table IV.

Comparing kiln characteristics and efficiencies in two different production areas in the Democratic Republic of Congo.

Area

Kiln characteristics

Mass wood $(\mathrm{kg})$

Humidity of wood (\%)

Mass of charcoal (kg)

$\%$ of unburnt wood

Efficiency (yield/ mass)

Nett efficiency (yield/ mass dry wood)

\begin{tabular}{|r|r|r|r|r|r|}
\hline \multicolumn{3}{|c|}{ YMAB production area } & \multicolumn{3}{c|}{ PB production area } \\
\hline & Mean & St. Dev. & N & Mean & St. Dev. \\
\hline 10 & & & & & \\
\hline 10 & $6,158.1$ & $2,225.5$ & 10 & $7,243.2$ & $3,950.4$ \\
\hline 10 & 35.4 & 3.7 & 10 & 25.6 & 9.4 \\
\hline 10 & 464.6 & 232.5 & 10 & $1,407.8$ & 661.4 \\
\hline 10 & 7.4 & 7.5 & 10 & 5.5 & 2.4 \\
\hline 10 & 7.4 & 2.9 & 10 & 20.5 & 4.2 \\
\hline
\end{tabular}

undertaking regular monitoring of the kiln (Projet Makala, 2012). In this area, charcoal production has been a common activity since the 1960 s. Many producers consider themselves 'professionals' and there have been several initiatives since the 1990s to train improved charcoal production practices, by CATEB $^{1}$ (Centre d'Adaptation des Techniques Énergie-Bois) and the Centre de Recherche Forestière de Kinzono, linked to the Mampu woodfuel plantation and agroforestry scheme, the Makala project from 2009 until 2013 and the Netherlands Development Organisation (SNV) in 2014 and 2015. Producers in the region report that they have received training by other operators, which suggests continuation of knowledge sharing (Projet Makala, 2011). The high pressure on forest resources in the area and high prices for the product in the markets of Kinshasa may also have fuelled producers' interest for uptake of improved techniques with higher yields. The production process observed near YMAB is quite different from $\mathrm{PB}$, with lower efficiencies linked to poor quality construction of the earth kiln cover, lack of monitoring, and negligence of the kiln. There is no intended practice of drying wood before carbonisation and ventilation of the kiln is less well controlled with none of the YMAB producers using the technique of digging ventilation holes before constructing the kiln. Producers in the YMAB area have not professionalized their activity and prioritize their farming activities. There has been no training on charcoal making in the region (Projet Forêts, Data baseline study). In the area of YMAB, the earth to cover the kilns contained at times too much clay, which caused breaking of the kiln cover and subsequent unintended burning due to increased oxygen availability. This issue was not observed in the PB area with sandy soils.

The institutional framework for charcoal making is officially the same in both Provinces under Congolese law, with several legal options for woodfuel production and trade, including obtaining of cutting and carbonisation permits (Sola et al., 2019). In practice, most charcoal production is informal throughout the country and in both areas producers generally do not possess any formal permit. On Plateau Bateke, woodfuel producers access tree resources under customary rules, typically accessing land through either customary land rights, or renting of land, or buying trees from the landowner or village chief, involving a payment in cash or in kind (Schure et al., 2015; Vermeulen et al., 2011). These patterns of accessing land are well-embedded and follow local rules. While respecting these rules and relations, producers obtain access to trees and charcoal making has been a common and accepted activity in the region, where forest officials do not have the means to control on-site. Issues of illegality, control and bribery are only encountered later, during transportation to Kinshasa and in the markets. Yet, producers and transporters pay less under existing informal arrangements than they would if they pay for the legally required permits and fees (Schure et al., 2013a).

NearYMAB, producers operate either in old rubber plantations, officially owned by a local agricultural research station (INERA), or on their traditional lands in and around the MAB reserve. Officially, charcoal making in the INERA concession is forbidden. Most producers of the kilns observed (based in Okito) access rubber plantations illegally without permission by INERA. INERA does not regularly monitor its plantations as there is a general lack of capacity for control and management of these woodlands. The illegal status of production in the concession does not impose any immediate issues to the producers who operate openly and indeed supply these same INERA officials with charcoal. The producers accessing traditional lands follow local rules on who can access, with certain restrictions on forbidden zones, and pay (cash or in kind) compensation for trees. There is confusion as to whether these producers do enter the reserve or not, as boundaries are unclear to villagers. In the central zone of the YMAB, all exploitation activities are officially forbidden. In the transition zone, exploitation needs prior approval of MAB agents. In reality, charcoal makers undertake carbonisation in the transition zone without formal authorization. According to MAB agents, charcoal producers enter the transition zone frequently. In 2016, MAB eco guards made around 10 arrests, with this modest number mainly due to low controlling capacity (Projet Forêts, Data baseline study).

In sum, the large differences in efficiency of woodto-charcoal conversion between the areas seem partly an outcome of the fact that the activity is much better established on the Plateau Bateke with a long history of capacity enhancement and skill building of producers. The activity in this area is informal, yet recognized, and well embedded in customary institutions (Schure et al., 2015). In contrast,

${ }^{1}$ CATEB is a specialized technical service of the Ministry of Environment that was created in 1983 to improve use of wood energy in the DRC. 
producers in the YMAB area have less capacity conducting good quality charcoal processing as they have never received training. In addition, they operate in a more uncertain institutional environment, where, especially in the YMAB transitions zone, they risk being arrested while conducting their activities. How this uncertainty of ownership and access to trees affects quality of production process was shown at one of the observed kiln sites, where a conflict over ownership of the trees eventually led to negligence of the kiln and low yields.

\section{Discussion and conclusion}

\section{Lessons on improving carbonisation in SSA context and role of enhancing capacities and enabling institutional context}

With charcoal remaining an important household energy source throughout SSA in the foreseeable future, improving sustainability of charcoal value chains receives renewed attention. Improving efficiency of the carbonisation process is one of the interventions that can have high potential gains in saving wood input and reducing GHG emissions. Options vary from simple adaptations, such as adding a chimney to the existing kiln, to industrial continuous

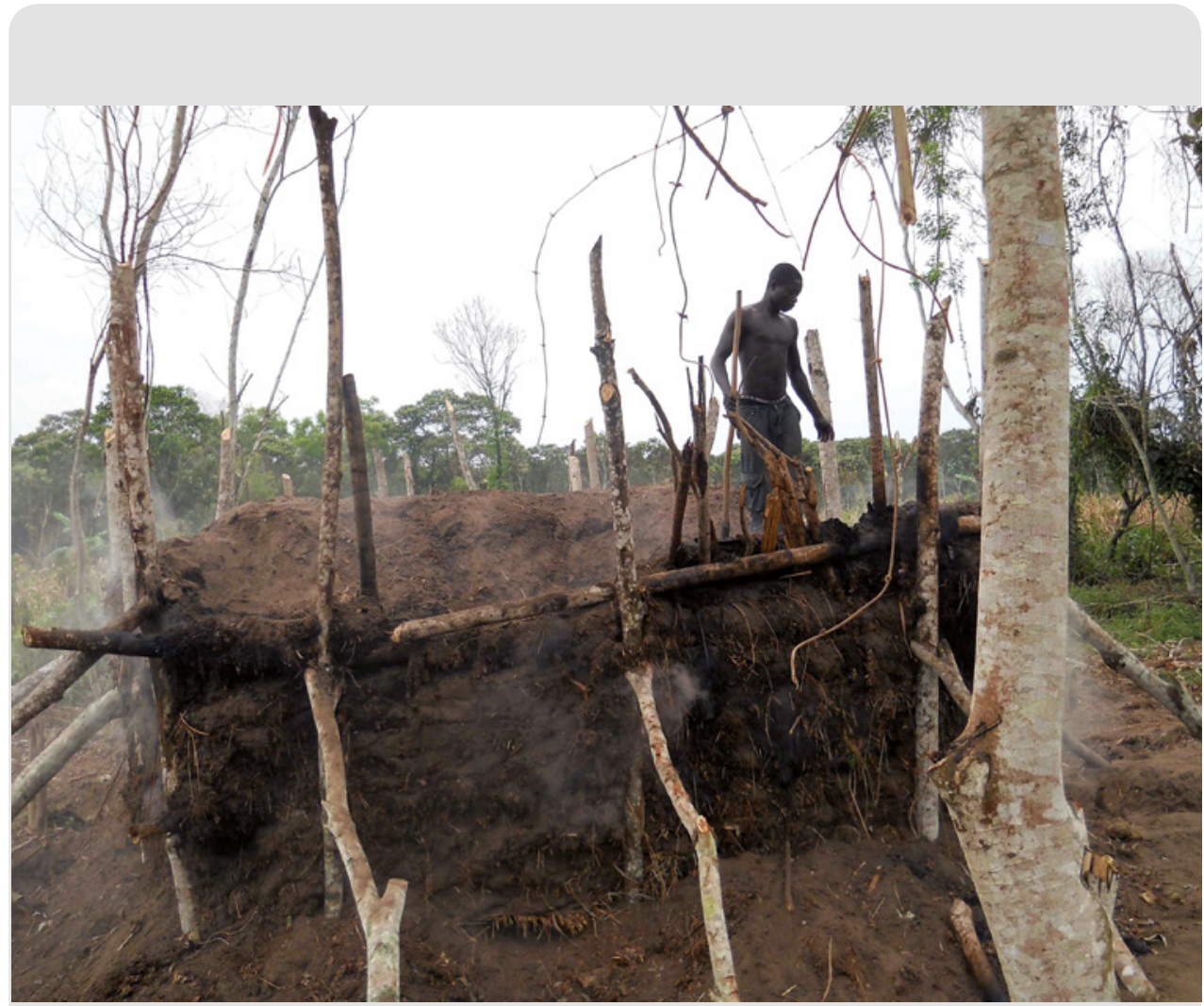

Photo 2.

Charcoal kiln on Plateau Bateke, Makala Project.

Photo D. Kalala, 2011. operation retorts and co-generation of heat and electricity. Despite efforts aimed at introducing improved kiln technology in SSA, uptake remains low due to relatively high investment costs needed, lack of training and impracticality of some of the kiln techniques within the given context. In addition, regulations that are generally neither implemented nor adapted to local conditions result in operators mostly working outside the legal framework and in an environment that is more conducive to illegal activities, involving quick and unsustainable practices, than to improvements.

Review of 5 initiatives that took an integrated approach to introducing improved kiln techniques, illustrates needs in terms of technical and capacity needs of producers and an enabling environment of appropriate institutions and governance (table $V$ ).

The case study lessons and field data extracted underline the importance of coupling technical solutions with wider capacity and awareness needs and promoting an enabling framework for charcoal production. The importance of charcoal makers' capacities and skills corroborates findings of others that technologies introduced need to be locally appropriate, acceptable to producers and need to be linked to training and education (van Beukering et al., 2007; Namaalwa et al., 2009; Kammen and Lew, 2005). This paper underlines that the appropriation of improved kiln techniques among charcoal producers depends on sufficient training of charcoal producers and on awareness on the advantages of improving kiln efficiencies. Awareness for improved charcoal processes is not only needed at the level of production, but also at the level of retail and consumption and among state agencies at different levels to support this.

In addition, the institutional framework contributes to shaping the enabling environment for providing incentives to efficient production methods and guidelines on preferred improved carbonisation techniques. Improved policies or financial mechanisms could include a stumpage fee or harvest quota, tax incentives, voluntary certification initiatives, or finance mechanisms such as through voluntary carbon markets or climate funds (FAO, 2017b; GIZ, 2015). Options for more sustainable charcoal require enabling policies, inclusiveness of more vulnerable actors and sustainably 
managed wood resources. Light monitoring mechanisms and systems to incentivize more sustainable practices to compete with illegally produced charcoal are needed. The various cases presented suggest that an opposite reality, where producers are forced to work in uncertain and ambiguous circumstances, is more likely to have them construct kilns in quick and inefficient manners instead of investing in improved practices and taking time for drying of the wood and frequent monitoring of the carbonisation process. In the forests near the Yangambi Man and Biosphere Reserve in the DRC and also on private farmlands with eucalyptus in
Rwanda, operators feel that their activities have to be conducted away from public scrutiny, in remote areas, sometimes at night-time and as quick as possible. These conditions force operators to trade off quality and quantity of production for faster, albeit much less efficient, production. This is yet another issue linked to the informal character of woodfuel production, besides criminalization, over-exploitation of natural resources and forgone tax revenues to governments (Mwampamba et al., 2013; Schure et al., 2013b).

Solutions beyond the kiln, including the aspects of capacity enhancement, acceptability and enabling

Table V.

Lessons on enabling factors for improving charcoal processes.

\section{Technical and capacity needs}

Context-specific kiln solutions, with suitable and available materials, acceptable to producers and considering transportation limits and wood sizes

Training for capacity enhancement technical skills charcoal producers combined with awareness raising on benefits

Access to upfront finances (via partnership with private sector or microcredits) for investments in improved kilns

Facilitation and capacitating of producer groups or cooperatives and recognize their legal status

Technical supervision and further researching and optimizing efficiencies

\section{Institutions and governance}

Facilitation of access to permits and simplification of taxation

Linking technical requirements to sustainable sourcing and management plans, including tenure rights

Creating awareness about improved charcoal processes among policy makers at different levels

Lighting mechanism to monitor use of improved kiln techniques (e.g. self-monitoring/ peer-to-peer by cooperatives).

Mechanism to incentivize more sustainably produced charcoal to compete with illegally produced charcoal

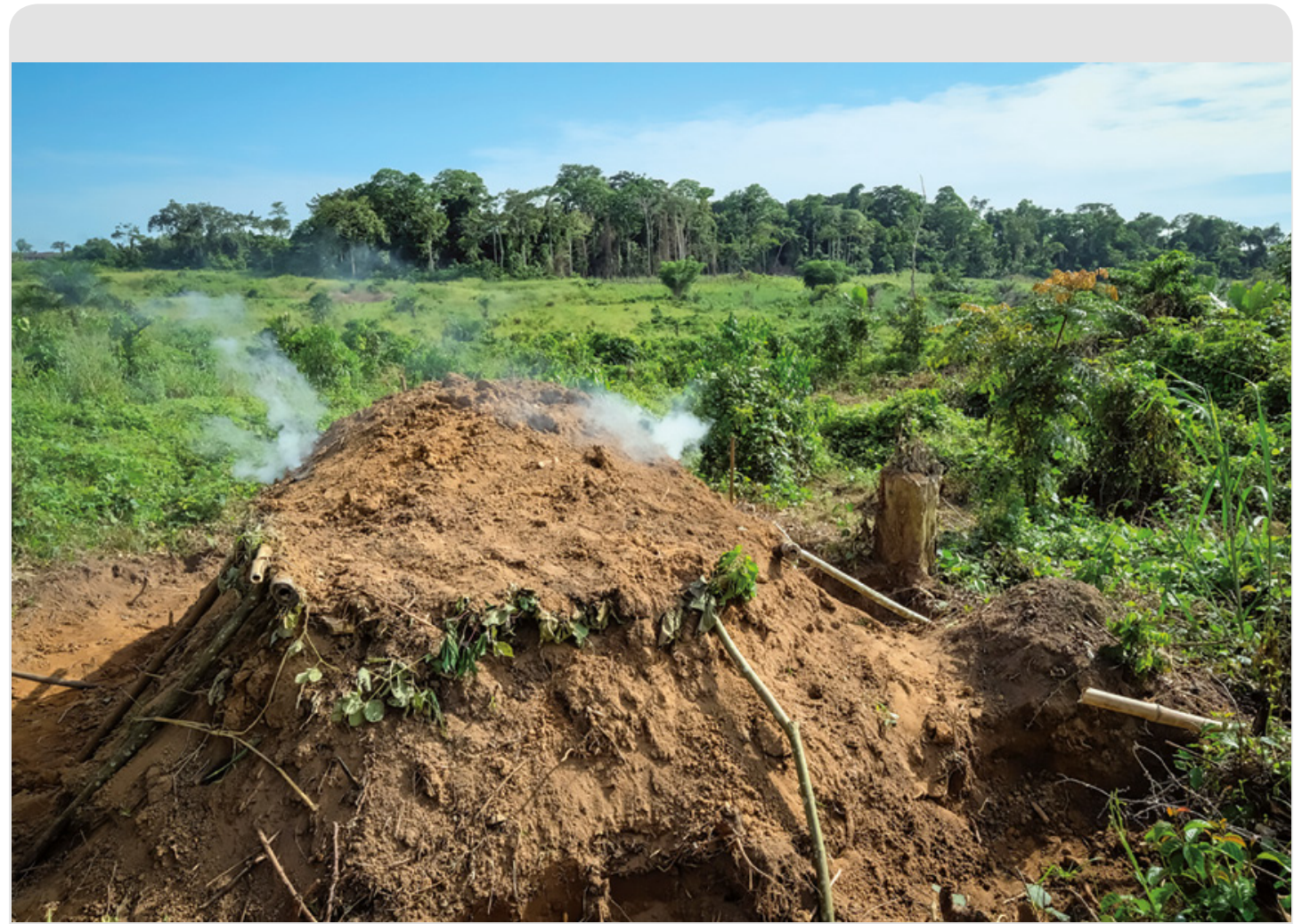

Photo 3.

Charcoal kiln in Yangambi landscape.

Photo CIFOR/A. Fassio 2017. 
institutional framework identified in this paper, co-determine success or failure of improved kiln techniques and related socio-ecological outcomes. Further development of in-context appropriate solutions in partnership with producers, while reinforcing an enabling institutional context, will enhance the potential for more sustainable woodfuel value chains.

\section{Acknowledgements}

The authors are grateful for contributions and revisions of the case studies by Christian Burren, Richard Knodt, Didier Hubert, Sabin Murererehe and Mary Njenga. The authors thank the anonymous reviewers for their detailed comments on earlier drafts of the paper. The data and lessons presented on charcoal efficiency of kilns in the Democratic Republic of Congo was collected in the context of two different projects, both funded by the European Union: the Makala project on 'Sustainable Management of Woodfuel in the Democratic Republic of Congo (2009 - 2013), coordinated by the French Agricultural Research Centre for International Development (CIRAD) and the Forest project "Formation, Recherche, Environnement dans la Tshopo" (Training, research and environment in the Tshopo Province), implemented by CIFOR and partners. The content of this paper is the sole responsibility of the authors and can in no way be taken to reflect the views of the European Union.

Annex 1.

Characteristics of the kilns surveyed in Yangambi Man and Biosphere Reserve, Democratic Republic of Congo.

\begin{tabular}{|c|c|c|c|c|c|c|}
\hline$\underset{\text { Kiln }}{\mathbf{N}}$ & $\begin{array}{l}\text { Mass of wood } \\
\text { input (kg) }\end{array}$ & $\begin{array}{c}\text { Humidity } \\
\text { of wood }\end{array}$ & $\begin{array}{c}\text { Mass of } \\
\text { charcoal (kg) }\end{array}$ & $\begin{array}{l}\% \text { unburnt } \\
\text { wood }\end{array}$ & $\begin{array}{c}\text { Efficiency } \\
\text { (mass of charcoal } \\
\text { leaving kiln/ weight } \\
\text { mass wood entering kiln) }\end{array}$ & $\begin{array}{l}\text { Efficiency } \\
\text { (yield / mass } \\
\text { dry wood) }\end{array}$ \\
\hline 1 & 4,550 & $30 \%$ & 425 & $11 \%$ & $9 \%$ & $16,0 \%$ \\
\hline 2 & 3,934 & $32 \%$ & 173 & $16 \%$ & $4 \%$ & $8,4 \%$ \\
\hline 3 & 4,314 & $40 \%$ & 367 & $3 \%$ & $9 \%$ & $14,9 \%$ \\
\hline 5 & 5,786 & $39 \%$ & 515 & $4 \%$ & $9 \%$ & $15,7 \%$ \\
\hline 6 & 9,072 & $31 \%$ & 381 & $0 \%$ & $4 \%$ & $6,1 \%$ \\
\hline 7 & 6,475 & $37 \%$ & 579 & $1 \%$ & $9 \%$ & $14,5 \%$ \\
\hline 8 & 9,250 & $41 \%$ & 684 & $1 \%$ & $7 \%$ & $12,6 \%$ \\
\hline 9 & 6,726 & $34 \%$ & 822 & $2 \%$ & $12 \%$ & $19,2 \%$ \\
\hline
\end{tabular}

Annex 2.

Characteristics of the kilns surveyed on Plateau Bateke.

\begin{tabular}{|c|c|c|c|c|c|c|}
\hline$\underset{\text { Kiln }}{\mathbf{N}}$ & $\begin{array}{l}\text { Quantity of } \\
\text { wood (kg) }\end{array}$ & $\begin{array}{l}\text { Average } \\
\text { humidity } \\
\text { of wood }\end{array}$ & $\begin{array}{c}\text { Weight of } \\
\text { charcoal (kg) }\end{array}$ & $\%$ unburnt & $\begin{array}{c}\text { Efficiency } \\
\text { charcoal/ } \\
\text { weight wood }\end{array}$ & $\begin{array}{l}\text { Efficiency } \\
\text { (yield/ mass } \\
\text { dry wood) }\end{array}$ \\
\hline 2 & 8,000 & $34 \%$ & 1,179 & $4 \%$ & $15 \%$ & $24 \%$ \\
\hline 3 & 5,999 & $26 \%$ & 999 & $5 \%$ & $17 \%$ & $23 \%$ \\
\hline 4 & 4,712 & $23 \%$ & 945 & $7 \%$ & $20 \%$ & $28 \%$ \\
\hline 6 & 6,171 & $18 \%$ & 1,634 & $5 \%$ & $27 \%$ & $32 \%$ \\
\hline 7 & 3,484 & $25 \%$ & 779 & $9 \%$ & $22 \%$ & $31 \%$ \\
\hline 8 & 4,593 & $14 \%$ & 1,212 & $7 \%$ & $26 \%$ & $31 \%$ \\
\hline 9 & 3,460 & $13 \%$ & 820 & $9 \%$ & $24 \%$ & $28 \%$ \\
\hline 10 & $\begin{array}{c}15,837 \\
\text { e: Projet Makal }\end{array}$ & $40 \%$ & 2,954 & $2 \%$ & $19 \%$ & $31 \%$ \\
\hline
\end{tabular}




\section{References}

Antal M. J., Grønli M., 2003. The art, science, and technology of charcoal production. Industrial \& Engineering Chemistry Research, 42: 1619-1640. https://pubs.acs.org/ doi/10.1021/ie0207919

Angwere Onekon W., Kipchirchir K. O., 2016. Assessing the effect of charcoal production and use on the transition to a green economy in Kenya. Tropical and Subtropical Agroecosystems, 19 (3): 327-335. http://www.revista.ccba.uady.mx/ ojs/index.php/TSA/article/view/2243/1036

van Beukering P. J. H., Kahyarara G., Massey E. E., Prima S. D., Hess S. M., Geofrey V., 2007. Optimization of the charcoal chain in Tanzania. Working Paper 07/03. Amsterdam, Vrije Universiteit, 44 p. http://dare.ubvu.vu.nl/bitstream/handle/1871/48175/198944.pdf?sequence=1

BTG Biomass Technology Group, 2010. Making charcoal production in Sub Saharan Africa sustainable. Utrecht, NL Agency, 59 p. https://english.rvo.nl/sites/default/files/2013/12/ Report\%20Charcoal\%20-\%20BTG\%20-\%20NPSB 0.pdf

Chidumayo E. N., Gumbo D. J., 2013. The environmental impacts of charcoal production in tropical ecosystems of the world: a synthesis. Energy for Sustainable Development, 17 (2): 86-94. https://www.sciencedirect.com/science/article/ pii/S0973082612000476

de Miranda R. C., Bailis R., de Oliveira Vilela A., 2013. Cogenerating electricity from charcoaling: A promising new advanced technology. Energy for Sustainable Development, 17 (2): 171176. https://www.sciencedirect.com/science/article/pii/ S0973082612000890

DFS, EMS, 2016. Final report and action plan for improvement of charcoal value chain in Rwanda. Republic of Rwanda, Ministry of Infrastructure, Belgian Development Agency, 56 p.

Doumenge C., Palla F., Scholte P., Hiol Hiol F., Larzillière A. (Eds.), 2015. Aires protégées d'Afrique centrale - État 2015. OFAC, République Démocratique du Congo, Cameroun, 256 p. https://www.observatoire-comifac.net/docs/edAP2015/ FR/EdAP 2015 Les aires protegees.pdf

Etter H., Sepp S., Ackermann K., Plugge D., Schauer M., 2014. Modernization of wood energy in northern Madagascar. ETFRN News, 56: 146-152. http://www.eco-consult.com/fileadmin/ user upload/pdf/ETFRN - Modernization of WE in Madagascar.pdf

FAO, 2017a. The charcoal transition: greening the charcoal value chain to mitigate climate change and improve local livelihoods. Rome, Italy, FAO, 184 p. http://www.fao.org/3/ai6935e.pdf

FAO, 2017b. Incentivizing sustainable wood energy in sub-Saharan Africa. Rome, Italy, FAO, 11 p. http://www.fao.org/3/ai6815e.pdf

FAO, 2018. FAOSTAT. Data 2016. Rome, Italy, FAO. http:// www.fao.org/faostat/en/

Girard P., 1992. Techniques et matériels de carbonisation. Contrôle de performances. Bois et forêts des tropiques, 232: 53-65. http://revues.cirad.fr/index.php/BFT/article/ view/19747
Girard P., Napoli A., 2005. La pyrolyse. In : Schenkel Y., Benabdallah B. (eds). Guide Biomasse Énergie. Deuxième édition. Organisation internationale de la francophonie, Les Publications de l'IEPF, 163-182. https://www.ifdd.francophonie.org/ media/docs/publications/248 Guide biomasse 2005.pdf

GIZ, 2015. Towards sustainable modern wood energy development: Stocktaking paper on successful initiatives in developing countries in the field of wood energy development. GIZ, GBEP, 79 p. http://www.globalbioenergy.org/fileadmin/ user upload/gbep/docs/giz2015-en-report-wood-energy. $\underline{\mathrm{pdf}}$

GIZ, Eco Consult, Coopération Allemande, 2016a. Amélioration de la chaîne de valeur du charbon de rebuts de scierie dans la région de l'Est Cameroun, 50 p.

GIZ, Eco Consult, Coopération Allemande, 2016b. Programme d'appui à la mise en œuvre de la stratégie de développement du secteur rural volets forêts environnement. État des lieux de la chaîne de valeur du charbon de rebuts de bois de scierie à l'est Cameroun. 95 p.

Gond V., Dubiez E., Boulogne M., Gigaud M., Péroches A., Pennec A., et al., 2016. Dynamics of forest cover and carbon stock change in the Democratic Republic of Congo: case of woodfuel supply basin for Kinshasa. Bois et Forêts des Tropiques, 327: 19-28. https://doi.org/10.19182/bft2016.327.a31293 IEA, 2017. Energy Access Outlook 2017. From poverty to prosperity. OECD/IEA., 140 p. https://webstore.iea.org/ weo-2017-special-report-energy-access-outlook

liyama M., Neufeldt H., Dobie P., Njenga M., Ndegwa G., Jamnadass R., 2014. The potential of agroforestry in the provision of sustainable woodfuel in sub-Saharan Africa. Current Opinion in Environmental Sustainability, 6: 138-147. https://www.sciencedirect.com/science/article/pii/S1877343513001966

Kammen D. M., Lew D. J., 2005. Review of technologies for the production and use of charcoal. Renewable and Appropriate Energy Laboratory Report. Berkeley, University of California, 19 p. http://rael.berkeley.edu/old drupal/sites/default/ files/very-old-site/Kammen.charcoal.pdf

Malimbwi R. E., Zahabu E., Kajembe G. C., Luoga E. J., 2000. Contribution of charcoal extraction to deforestation: experience from CHAPOSA Research Project. Morogoro, Sokoine University of Ariculture, 14 p. http://coastalforests.tfcg.org/ pubs/Char Deforestation CHAPOSA.pdf

Mutimba S., Barasa M., 2005. National Charcoal Survey: Summary Report Exploring the Potential for a Sustainable Charcoal Industry in Kenya. Nairobi, Energy for Sustainable Development Africa (ESDA), $74 \mathrm{p}$.

Mwampamba T. H., Ghilardi A., Sander K., Chaix K. J., 2013. Dispelling common misconceptions to improve attitudes and policy outlook on charcoal in developing countries. Energy for Sustainable Development, 17 (2): 75-85. https://www.sciencedirect.com/science/article/pii/S0973082613000021

Namaalwa J., Hofstad O., Sankhayan P. L., 2009. Achieving sustainable charcoal supply from woodlands to urban consumers in Kampala, Uganda. International Forestry Review, 11 (1): 64-78. https://bioone.org/journals/international-forestry-review/volume-11/issue-1/ifor.11.1.64/Achieving-Sustainable-Charcoal-Supply-from-Woodlands-to-Urban-Consumers-in/10.1505/ifor.11.1.64.short

Oduor N., Githiomi J., Chikamau B., 2006. Charcoal Production Using Improved Earth, Portable Metal, Drum and Casamance Kilns. Karura, Kenya, Forestry Research Institute (KEFRI), 20 p. https://www.fornis.net/node/272 
Ojelel S., Otiti T., Mugisha S., 2015. Fuel value indices of selected woodfuel species used in Masindi and Nebbi districts of Uganda. Energy, Sustainability and Society, 5 (1): 14. https://link.springer.com/article/10.1186/ s13705-015-0043-y

Owen M., van der Plas R., Sepp S., 2013. Can There Be Energy Policy in Sub-Saharan Africa without Biomass? Energy for Sustainable Development, 17: 146-152. https://www.sciencedirect.com/science/article/pii/S0973082612000749

Pinta F., Dubiez E., Kalala D., Volle G., Louppe D., 2013. Amélioration de la carbonisation en meule traditionnelle. In : Marien, J.-N., Dubiez E., Louppe D., Larzillière A. (Eds). Quand la ville mange la forêt : les défis du bois-énergie en Afrique centrale. France, Éditions Quæ, 27-44.

Projet Forêts, 2018. Diagnostic de la filière bois énergie de la Réserve de Biosphère de Yangambi. Kisangani, République démocratique du Congo, Projet Forêts, 61 p.

Projet Makala, 2011. Projet Makala - Bois énergie en RDC : Analyse de la filière des villes de Kinshasa et de Kisangani. Cameroun, CIFOR, 84 p. http://makala.cirad.fr/les produits/ publications/rapports/2011 analyse de la filiere bois energie des villes de kinshasa et de kisangani cifor

Projet Makala, 2012. La carbonisation traditionnelle : suivi de dix meules sur la zone des plateaux Batéké en périphérie de la capitale Kinshasa. Les Notes perspectives du Projet Makala, No 3, Mars 2012. http://makala.cirad.fr/index.php/projets/ content/download/11626/69594/file/Makala Notes\%20 perpective $\% 20$ n\%C2\%B03 web.pdf

Schenkel Y., Bertaux P., Vanwijnsberghe S., Carré J., 1997. Une évaluation de la technique de carbonisation en meule. Biotechnologie, Agronomie, Société et Environnement, 1 (2) : 113-124. http://agris.fao.org/agris-search/search. do?recordID=DJ2012082299

SE4ALL, 2015. Rwanda SE4ALLAction Agenda. Second Annual United Nations SE4ALL Forum, May 2015, 58 p. https://www. se4all-africa.org/fileadmin/uploads/se4all/Documents/ Country AAs/Rwanda Action Agenda.pdf

Sola P., Schure J., Eba'a Atyi R., Gumbo D., Okeyo I., Awono A., 2019. Woodfuel policies and practices in selected countries in Sub-Saharan Africa: a critical review. Bois et Forêts des Tropiques, 340: 5-19.

Schure J., Ingram V., Assembe-Mvondo S., Mvula-Mampasi E., Inzamba J., Levang P., 2013a. La filière bois-énergie des villes de Kinshasa et Kisangani. In : Marien, J.-N., Dubiez E., Louppe D., Larzillière A. (Eds). Quand la ville mange la forêt : les défis du bois-énergie en Afrique centrale. France, Éditions Quæ, 27-44.

Schure J., Ingram V., Sakho-Jimbira M. S., Levang P., Wiersum K. F., 2013b. Formalisation of charcoal value chains and outcomes in Central and West Africa. Energy for Sustainable Development, 17 (2): 95-105. https://www.sciencedirect. com/science/article/pii/S0973082612000452

Schure J., Dkamela G. P., van der Goes A., McNally R., 2014. An approach to promote REDD+ compatible wood-fuel value chains. In: McNally R. (ed.). Smart Development Works. The Hague, The Netherlands, SNV, 40 p. http://www.snv.org/ public/cms/sites/default/files/explore/download/140013 wood fuel 2.pdf
Schure J., Ingram V., Arts B., Levang P., Mvula-Mampasi E., 2015. Institutions and access to woodfuel commerce in the Democratic Republic of Congo. Forest Policy and Economics, 50: 53-61. https://www.sciencedirect.com/science/article/ $\mathrm{pii} / \mathrm{S} 1389934114001361$

Smeets E., Johnson F. X., Ballart-Tremeer G., 2012. Keynote Introduction: Traditional and improved use of biomass for energy in Africa. Chapter 1, $11 \mathrm{p}$.

Sparrevik M., Adam C., Martinsen V., Jubaedah Cornelissen G., 2015. Emissions of gases and particles from charcoal/ biochar production in rural areas using medium sized traditional and improved "retort" kilns. Biomass \& Bioenergy, 72 : 65-73. https://www.sciencedirect.com/science/article/pii/ $\underline{\text { S0961953414005170 }}$

United Nations, 2015. Transforming our world: the 2030 Agenda for Sustainable Development. United Nations, A/ res/70/1, p. 35. https://sustainabledevelopment.un.org/ post2015/transformingourworld

Vermeulen C., Dubiez É., Procès P., Mukumary S. D., Yamba T. Y., Mutambwe S., et al., 2011. Enjeux fonciers, exploitation des ressources naturelles et Forêts des Communautés Locales en périphérie de Kinshasa, RDC. Biotechnologie, Agronomie, Société et Environnement, 15 (4) : 535-544. https://popups. uliege.be/1780-4507/index.php?id=7911

Wartluft J. L., White S., 1984. Comparing simple charcoal production technologies for the Caribbean. Montserrat fuelwood/charcoal/cookstove project. USA, VITA, 22, 7 p.

Raghunathan N., Ansay F., Nsenga L., 2013. Gestion participative des Ressources Naturelles dans les Réserves de Biosphère. L'expérience du WWF dans les réserves de Luki, Yangambi (RDC) et Dimonika (République du Congo). WWF-Belgique, WWF-RDC, 27 p. https://wwf.be/assets/ Uploads/Images/PROJECTS/LUKI/Guide-de-gestion-participative-des-aires-protegees-en-RDC-259916.pdf

Bois et Forêts des Tropiques - Revue scientifique du Cirad
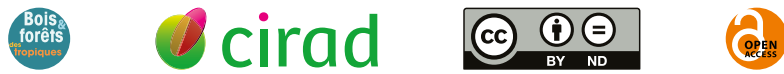

Cirad - Campus international de Baillarguet, 34398 Montpellier Cedex 5, France - Contact: bft@cirad.fr - ISSN: L-0006-579X 